\title{
Lift above Poverty Micro-Finance Bank, Rural-Women Financial Security and Crime Reduction Strategies in Nigeria: Evaluation of Selected Communities in Badagry, Lagos State, Nigeria
}

\author{
Haruna Ishola Abdullahi, Olayemi Oluwadamilola Amosun, Olayemi Oluwadamilola Amosun \\ $\&$ Babatunde Olufemi Akinyele \\ Federal University, Oye-Ekiti, Ekiti State, Nigeria \\ Email: harunism@gmail.com
}

\begin{abstract}
This paper assessed Lift above Poverty Organization (LAPO), rural-women financial security as means of crime reduction Lagos State, women are involved in entrepreneurship to avert criminalities like arm-robbery, kidnapping, cultism, online fraud, terrorism and other security challenge. The study employed cross sectional survey design and was descriptive, combining both qualitative and quantitative techniques. The secondary data were obtained through content analysis of journals, books and online resources. The data were analyzed with Statistical Package for Social Sciences version 20.0. Findings showed that $100 \%$ of the respondents were females, $72 \%$ of the respondents used credit facilities from LAPO for investments.
\end{abstract}

Keywords: LAPO, rural women, financial security, crime reduction, Badagry, Lagos State

\section{Introduction}

Poverty is a global issue, at international level the zeal to mitigate poverty especially among the developing nations led to creation of organizations like the International Monetary Funds, World Bank, International Bank for Economic Reconstruction and Development, The Economic Community of West African State. In developing courtiers, there are more than fifteen organizations that fight poverty. In Nigeria, there have been various strategies to combat poverty, from her independence in 1960. There were National Development Plans, which spanned over twenty years (Jideofor, 2012). During military regimes various arrangements were instituted, till present now there have been several other failed attempts by government to alleviate extreme poverty among the populace. According to the last reports by the World Poverty Clock over 92 million Nigerians live in extreme poverty, this means that more than half of the country population is currently affected; they spend below 1.9 Dollars per day, (Nigerian Bureau of Statistics, 2010). The World Poverty Clock uses indices like income, distribution and production supply by the World Bank and IMF .In the late 1980s LAPO Micro Finance Bank was established primary to give the people access to affordable loans to boost their financial security, the organization has recorded huge success in terms of provision of soft credit facilities to people at the grassroots, most of the beneficiaries of the loans were rural women who have been evidently applied them to establish small and medium enterprises thereby reduce poverty which most of the government establishments failed to achieved for many years. The study conducted by Armstrong and Zegher (2006), supported by Weatherburn (2002) extreme poverty is linked to high wave of crime in Nigeria, in recent times there has been unprecedented increase in the rate of crime like arm-robbery, kidnapping, theft, murder, suicide, child trafficking and drug trafficking, women were not exempted from these criminal acts. Hence, 
his study assessed LAPO, rural -women financial security and crime reduction strategies in Nigeria: - a study of selected communities, Badagry, Lagos State. The research was guided by the major research questions. What is the relationship between LAPO and crime reduction among rural women? Other specific questions are; what are the other areas of poverty alleviation by LAPO and rural populace?

\section{Literature Review}

\subsection{LAPO}

The acronyms is referred to as Lift above Poverty Organization, it is one of the micro finance banks that was licensed to operate in Nigeria under the control of the Central Bank of Nigeria. It was created in the late $80 \mathrm{~s}$ among its mandate were provision of soft credit to the lessprivileged individuals to improve their socio-economic status. Since its inception over one million customers have accessed credits (Abel and Emily eds. 1983). This microfinance bank has wider coverage and popularity in Nigeria, it's activities spread to rural communities in Nigeria. Rural women mobilize themselves in groups; each group has a leader and secretary with distinct name. This organization has reduced penury and misery through women entrepreneurship.

\subsection{Needs for Women Financial Security}

\subsubsection{Discrimination against Women}

As explained by Maggie (2003), there is no country where gender inequality does not exist, it occurs in every sector of social existence. In most societies women are considered as second class citizens and they are subjected to various degrees of sub-ordinations. In terms of access to loans. There are huge conditionality like collateral security, sureties and other administrative formalities to credit facilities. Most women in African lack these conditions hence; their access to credit facility is limited. LAPO has provided avenue for women to overcome these challenges through liberal loan requirements.

\subsubsection{Dominance of Informal Sector}

According to Aigbokhan, (2000), women has highest number among participants in the informal sector like tailoring, business centers, catering services, other small and business enterprises. There is need for financial security to boost their operational capital.

\subsubsection{Women Financial Capacity}

One of the rationales for LAPO financial security is promotion of good financial standing for the women group; this will promote their capacity to contribute to the societies in terms of their child education, family upkeep and other areas (Duffield, 2010).

\subsection{Strategies Adopted by LAPO}

As explained by John el tal., (2001)

\subsubsection{Right Target}

In order to ensure prudent utilization of loans and other credit facilities LAPO targets appropriate populace and ensure those that are needed loans have access to them as at when due

\subsubsection{Group Borrowing}

In other to boost financial safety, one of the strategies adopted is group lending; this enhances 
financial group commitments in terms of loan recovery and disbursement.

\subsubsection{Client Engagement}

One peculiarity of LAPO over other micro finance institution is dedication to improvement of the lots of its members who are women, before loan approval and disbursement is done the beneficiaries business feasibility is duly discussed and assessed.

\subsubsection{Multiple products and services}

LAPO offers various products and services that are targeted towards improvement of lives of the clients. It offer educational, ICT Information Communication Services, financial, health, energy services, household appliances in order to improve the living conditions of the its members.

\subsubsection{It provides Legal aid Disinheritance/ paternal responsibilities, domestic violence}

All these related services are targeted to improve the yearnings of their members. This gives LAPO customer's confidence in the organization and increase in membership drive.

\subsubsection{Health Services Small Scale Literacy}

Health is wealth; one of the rationales for LAPO is provision of health care services for both staff and clients on the ground strong commitment to provision of health care. It offers literacy services to its members to boost their financial educational and general human development.

Figure 1. LAPO Members in a Weekly Meeting

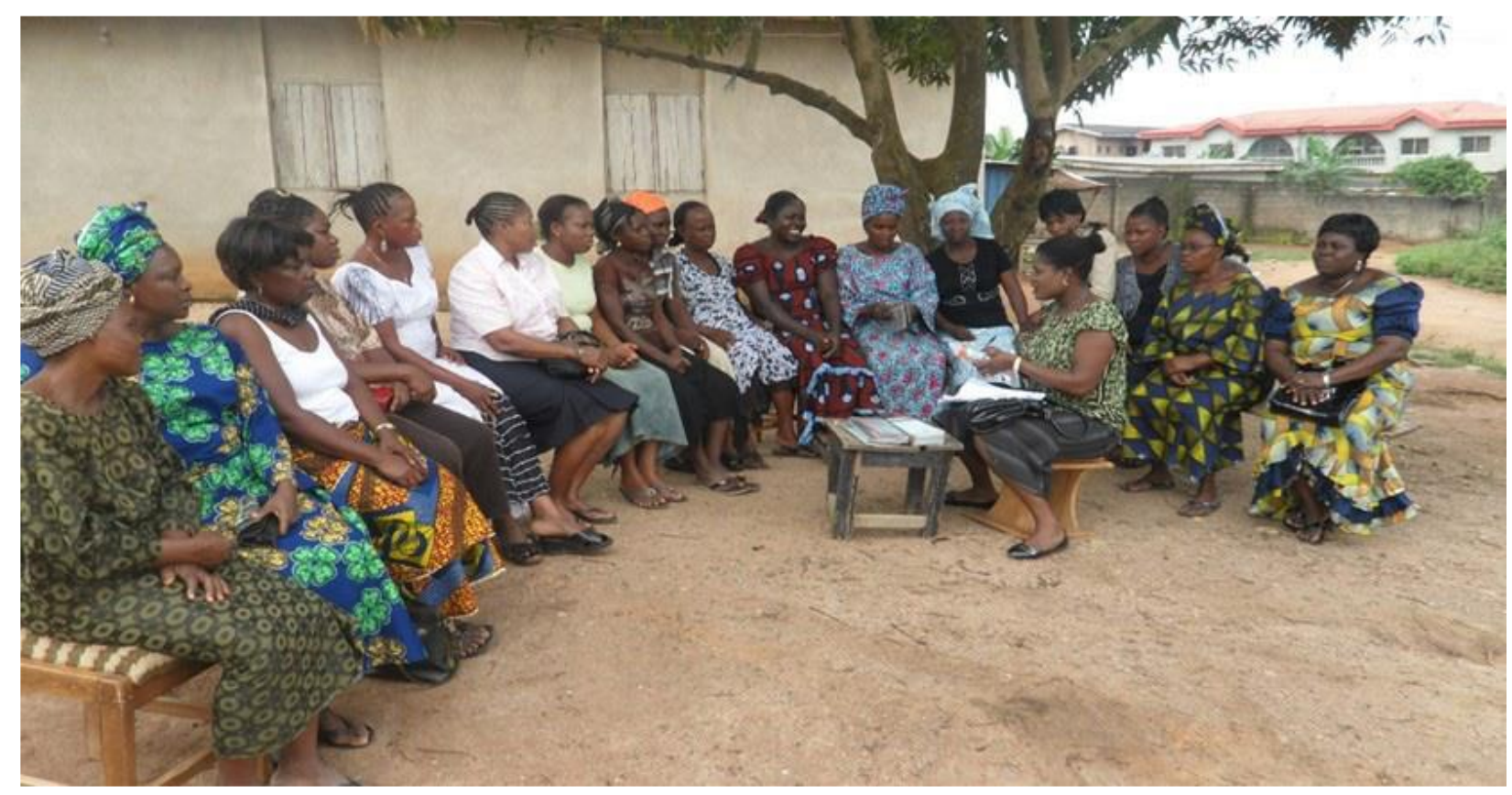

Source: https://en.wikipedia.org/wiki/Lift_Above_Poverty_Organization

\subsection{Financial Security}

As defined by Yusuf (2014), it is the easy access to various credits facilities by people at a particular period of time to overcome financial stress and its unsuitable circumstances. The opposite of financial security is financial insecurity. Financial security is the engine of life; money provides capital for businesses to thrive. According to AFI (2017) financial insecurity 
leads to social and psychological problems in a social structure. There are many benefits of financial security. It provides opportunities for investments and creation of wealth; this reduces the level of unemployment in the country and its undesirable consequences like crime, violence and the anti-social behavior. Idleness or unemployment has been established as the major cause of crimes in Nigeria and other African countries. The establishment of LAPO has created ample opportunities to the people especially the women to invest in gainful business ventures inancial security has the following components (Obodo, 2014).

Table 1. Percentage of Population living in extreme Poverty SDGI Status

\begin{tabular}{|l|l|l|}
\hline Nigeria & 46.7 & Poverty rising \\
\hline Democratic Republic of Congo & 77 & Poverty rising \\
\hline Ethiopia & 23.4 & On track \\
\hline Tanzania & 35 & Off track \\
\hline Mozambique & 61.8 & Off track \\
\hline Kenya & 30 & Off track \\
\hline Uganda & 34.2 & Off track \\
\hline South Africa & 24.6 & Off track \\
\hline South Sudan & 93 & Poverty rising \\
\hline Zambia & 57.2 & Poverty rising \\
\hline
\end{tabular}

Source: https://borgenproject.org/organizations-fighting-poverty-developing-countries/

2.4.1 Components of Financial Security :Financial security has the following components (Obodo, 2014)

Effective Budget; Realistic budgeting is key to financial security, a failure to plan is planning to fail; rational human beings who is conscious of his or future should be able to assess its income and expenditure and know his offer pressing needs and appropriate time to satisfy them.

Long time Need: One of the retrain for effective financial security is ability of person to plan for his or her long time needs like investment. Children school; fees and other financial obligations (Obodo, 2014).

Scale of Preferences: In a bid to avert financial crises is need to spend on those items that required immediate needs and suspend those items that are of pressing needs.

Tracking Long Time Needs. There is need to enhance present and longtime needs as solidification for financial peace and harmony.

Good Financial Experts. There need for guidance in very field of human endeavor, in everything, this will promote effective utilization of resources. 


\subsection{Crimes Committed by Women-folks in Nigeria}

Sighted in Heidersohn (2002)

Violence. One of the criminal activities in Nigeria is violence; violence could be defined as act that could be defined as any activity that could lead to loss of lives, property or physical or psychological harm in any degree. Violence has different varieties this could be domestic, political and other form of violence. The frequency of domestic violence is unacceptable; many families have been destroyed in the acts (Stubbs, 2004).

Theft. Taking the property of others without their consent, this crime is committed in various degrees; there are minor and major thieves (Bottom, 2003).

Kidnapping: In recent times the spate of kidnapping in Nigeria is worrisome, both print and electronic media are fraught with reports of kidnapping. These crime is committed by both male and female group, the female kidnappers target children and are usually sent by the rituals. Kidnappers target wealthy and highly placed members of society who can afford to pay huge ransom.

Murder. One of the heinous crimes in Nigeria, it is a serious crime that involves loss of lives. There are cases of domestic murder, which involve husbands and wives. Other of murder is matricide and fratricide. The current herd men attacks have resulted in murder of over millions of persons (Friedrichs, 2009).

Vandalism. Other type of criminal activities that are perpetrated in Nigeria is vandalization of oil and gas installation which led to disruption of supply of energy in the economy. The aftermath of this crime is burdensome in terms of inferno which has consumed millions of people and revenue loss to the government; women have been evidently involved in this act.

Table 2. The Ten Countries with Gender Gap Pay in 2018

\begin{tabular}{|l|l|l|}
\hline $\mathrm{S} / \mathrm{N}$ & COUNTRY & PERCENTAGE. Euro Average 16.2 \\
\hline 1 & Estonia & 28.3 \\
\hline 2 & Australia & 22.9 \\
\hline 3 & Czech Republic & 22.1 \\
\hline 4 & Slovakia & 21.6 \\
\hline 5 & Germany & 21.6 \\
\hline 6 & Span & 18.8 \\
\hline 7 & United Kingdom & 18.3 \\
\hline 8 & Finland & 18.0 \\
\hline 9 & Netherlands & 16.2 \\
\hline
\end{tabular}




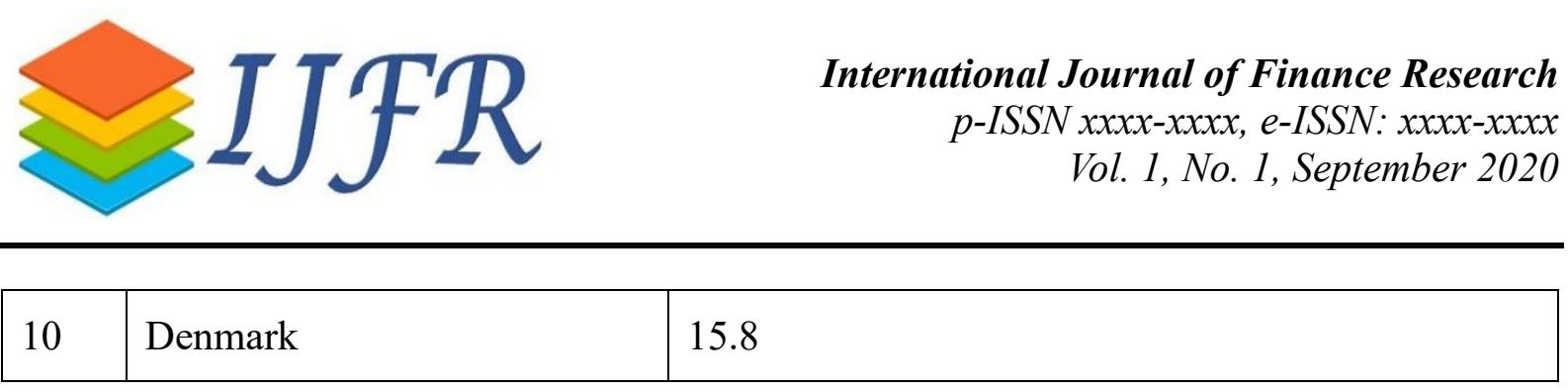

Source:https://en.wikipedia.org/wiki/Gender_equality\#/media/File:EU_27_Gender_Pay_Gap_2018.png,

2.6 The links among LAPO, Women Financial Security and Crime Committed by Women in Nigeria

LAPO is committed to uplift of the social and economic well beings of the women through soft loans and other means of alleviation their difficulties. Most women who engaged in criminal activities have advanced unemployment as reason for that. LAPO as a credible financial institution provides multiple avenue for women to access loans for their self-reliance and entrepreneurship.

\subsection{Theoretical Framework}

Strain theory by Robert King Merton. According to Robert King Merton, every society has social goals and institutional means of achieving those goals (Agnew, 2001). When people are prevented from achieving those goals, through lack of opportunities they engage in negative innovative acts, examples of those innovative acts are criminal activities. Most women are involved in criminal acts because of their inability to achieve social goals like financial success.

Feministic Theory. This theory addresses various issues like inequality, oppression, patriarch, stereotyping and other forms of abuse against women (Dow, 2009). It was propounded by Marry Wollstonecraft in 1787 and other followers of the theory have made tremendous amendments to it. The theory dwells on issues surrounding female inequality like patriarchy, oppression, discrimination against women in politics, economy, education and other aspects of social engagements. LAPO is one viable economic institution that addresses issues affecting financial incapacity of women by giving those opportunities to access loans and other moderate financial instruments (Linda, 2000).

Research Hypothesis Based on the aforementioned introduction and literature review, this research aims at testing the following hypothesis

Null Hypothesis

$\mathrm{H}_{\mathrm{o}}$ : There is no relationship between LAPO`s capacity to create financial security and women commission of criminal activities

Alternative Hypothesis

$\mathrm{H}_{1}$ : There is a relationship between LAPO`s capacity to create financial security and women commission of criminal activities.

\section{Research Method}

The study employed cross sectional survey design and was descriptive, combining both qualitative and quantitative techniques. The primary data were obtained by administering 200 questionnaires to the active women-clients of LAPO in Iworo-Awori, Ajido, Imeke and Ilado communities in Badagry, Lagos, 174 questionnaires were returned consequently the response rate was $87 \%$. Furthermore, simple and stratified random sampling techniques were adopted in distribution of questionnaires; fifty questionnaires were administered to each chosen community, the choice of those communities was motivated by availability of active LAPO members in them in groups. The secondary data were obtained through content analysis of 
journals, books and online resources; in this regard the meanings of LAPO, functions, financial security and crimes were explored. The data were analyzed with Statistical Package for Social Sciences version 20.0.

\section{Findings and Discussions}

Table 3. Socio-Demographic Characteristics of The Respondents

\begin{tabular}{|c|c|c|c|}
\hline & Socio - Demographic Characteristics & & \\
\hline \multirow[t]{3}{*}{1} & Sex & $\mathrm{N}$ & $\%$ \\
\hline & Females & 174 & $100 \%$ \\
\hline & & 174 & 100.0 \\
\hline \multirow[t]{7}{*}{2} & Age (years) & $\mathrm{N}$ & $\%$ \\
\hline & $20-30$ & 10 & 5.75 \\
\hline & $31-41$ & 37 & 21.26 \\
\hline & $42-52$ & 118 & 67.82 \\
\hline & $53-63$ & 7 & 4.02 \\
\hline & Above 64 & 2 & 1.15 \\
\hline & Total & 174 & $\mathbf{1 0 0 . 0 0}$ \\
\hline \multirow[t]{8}{*}{3} & Educational Status & $\mathrm{N}$ & $\%$ \\
\hline & No formal Education & 10 & 5.74 \\
\hline & Primary School & 30 & 17.24 \\
\hline & SSCE & 94 & 54.02 \\
\hline & NDE/DIPLOMA & 23 & 13.22 \\
\hline & Bachelor & 12 & 6.90 \\
\hline & Postgraduate & 5 & 2.87 \\
\hline & Total & 174 & 100.00 \\
\hline \multirow[t]{5}{*}{4} & Marital Status & $\mathrm{N}$ & $\%$ \\
\hline & Married & 149 & 85.63 \\
\hline & Divorce & 21 & 12.07 \\
\hline & Separated & 4 & 2.30 \\
\hline & Total & 174 & 100.00 \\
\hline
\end{tabular}

\begin{tabular}{|c|c|c|c|}
\hline 5 & $\begin{array}{llll}\begin{array}{l}\text { Monthly } \\
\text { employment }\end{array} & \text { Income } & \text { from } & \text { Self- } \\
\end{array}$ & $\mathrm{N}$ & $\%$ \\
\hline & Undecided & 7 & 4.02 \\
\hline & Below $\$ 5,000$ & 54 & 33.91 \\
\hline & $\$ 5,000-\$ 45,000$ & 59 & 31.03 \\
\hline & $\$ 46,000-\$ 86,000$ & 21 & 12.07 \\
\hline & $\$ 87,000-\$ 168,000$ & 16 & 9.10 \\
\hline & $\$ 169,000-\$ 209,000$ & 7 & 4.02 \\
\hline & $\$ 210,000--\$ 250,000$ & 8 & 4.60 \\
\hline & $\$ 251,000=\cong 291,000$ & 2 & 1.15 \\
\hline
\end{tabular}




\begin{tabular}{|l|l|c|c|}
\hline & Total & $\mathbf{1 7 4}$ & $\mathbf{1 0 0 . 0 0}$ \\
\hline & & & \\
\hline 6 & Self-employment Activities & $\mathrm{N}$ & $\%$ \\
\hline & Trading & 81 & 46.7 \\
\hline & Farming & 22 & 12.64 \\
\hline & Pure water production & 11 & 6.32 \\
\hline & Frying and sales of snacks & 35 & 20.11 \\
\hline & Others & 12 & 6.90 \\
\hline & No response & 13 & 7.47 \\
\hline & Total & 174 & 100 \\
\hline
\end{tabular}

From Table 3, all respondents were females; this implied that women were the major target of LAPO, $67.82 \%$ of the respondents felt within ages bracket of (42-52) years, this demonstrated their productive age to actively engage in production by channeling financial assistance from LAPO to more lucrative ventures and ability to return gains from investments. Furthermore, $54.02 \%$ of the respondents had SSCE as their highest educational attainment; this justifies the educational commitment of LAPO to their clients and the need to take advantage of education for enhanced productivity. In term of their marital status, $85.63 \%$ of the respondents were married and with this, they have some responsibilities to discharge to their families in terms of children education, moral upbringing and the entire society, as par their monthly income $31.03 \%$ of the respondents earned monthly income between $\$ 5,000-\$ 45,000$, this gives LAPO this vindicates LAPO commitment to improvement their financial capacity of the rural women in order to upgrade their income capability through soft loans, $46.7 \%$ of the respondents engage in trading of commodities, this promotes the goal of LAPO in advancing commercial commitment of its clients.

Table 4. Percentage distribution of the respondents by expenditure of credit facilities from LAPO

\begin{tabular}{|l|l|c|c|}
\hline & Usage of credit facilities from LAPO & $\mathrm{N}$ & $\%$ \\
\hline & Investment on business & 125 & 71.84 \\
\hline & Payment of child school fees & 20 & 11.49 \\
\hline & Payment of house rents & 17 & 9.77 \\
\hline & Other uses & 12 & 6.90 \\
\hline & Total & 174 & 100 \\
\hline
\end{tabular}

From table 4, 71.84\% of the respondents used credit facilities they obtained from LAPO for investment, 11.49 expended it on payment of school fees, and $9.77 \%$ used it for settlement of their house rents, and 6.90 for other purposes. This implies that most of the LAPO clients use the credit facilities for investment on their businesses and while other use remaining parts of credit facilities for other activities.

Table 5. Hypothesis Testing

\begin{tabular}{|l|l|l|l|l|l|l|}
\hline $\begin{array}{l}\text { Categories } \\
\text { of } \\
\text { Responses }\end{array}$ & Frequency & Percentage & $\mathbf{X}^{2}$ value & $\begin{array}{c}\text { Degree } \\
\text { of } \\
\text { Freedom }\end{array}$ & $\begin{array}{c}\text { Critical } \\
\text { Value }\end{array}$ & Remark \\
\hline
\end{tabular}




\begin{tabular}{|l|c|c|c|c|c|l|}
\hline Agree & 101 & 58.05 & & & & \\
Disagree & 49 & 28.16 & & & & \\
Undecided & 24 & 13.79 & 11.87 & 5 & 7.30 & Significant \\
Total & & 100 & & & & \\
\hline
\end{tabular}

Source: Field Survey, 2018.

As mentioned earlier, the Null hypothesis was, "There is no relationship between LAPO and rural women financial security and crime prevention". From Table 5, the calculated chi-square value of 11.87, with 5 degrees of freedom was than the table value of 7.30 , at $5 \%(0.05)$ level of significance hence, the alternative hypothesis is here accepted and the null hypothesis is rejected, therefore, there is relationship between LAPO financial security and crime prevention among rural women.

\section{Conclusion}

Findings from the research showed that there was significant relationship between LAPO financial security and crime prevention among rural women; $71.84 \%$ of the respondents spend their credit facilities from LAPO on business expansion. And LAPO concentrates mainly on the rural women's capacity development. The current crime wave in Nigeria could be mitigated through LAPO's enhanced financial capacity to rural women, because research has established relationship between women unemployment and their perpetration of criminal activities, credit expansion from LAPO and other financial institutions is a viable means of creating employment and capacity building among women folks. The study will be useful to rural women, community banks, Central Bank, commercial banks, NGOs that are involved in poverty reduction and researchers in the field of financial security and crime reduction can further explore other angle to the research like LAPO and rural poverty generally because this study concentrated on LAPO and rural women financial security towards crime alleviation.

\section{References}

Abel, E., \& Abel, E.K. (1983). The signs reader: Women, gender, and scholarship. Chicago: University of Chicago Press.

AFI. (2017).Women financing: A Case Study No.6

Agnew, R., (2001). Building on the foundation of general strain theory: Specifying the types of strain most likely to lead to crime and delinquency. Journal of Research in Crime and Delinquency, 38(4), 319-361

Aigbokhan, B. E. (2000). Poverty, growth and inequality in Nigeria: A case study. Retrieved from: unpan1.un.org.

Armstrong, C., \& Zegher, C.(2006). Women artists at the millennium. Massachusetts: October Books / MIT Press.

Åsberg, C., \& Lykke, N. (2010). Feminist technoscience studies. European Journal of Women's Studies, 17(4), 299-305.

Bottom, N.R. (2003). Employee dishonesty and crime in business in Protection Officer Training Manual, $7^{\text {th }}$ Ed.Butterworth-Henermann. New York, Curbing Crime and Corruption among Youth, Abuja, Unique Concepts Ltd

Bowers, \& Johnson. (2005). Domestic burglary repeats and space -time clusters. European 
Journal of Criminology, 2, 67-92

Dow, B. (2009). Feminist approaches to communication. In W. Eadie (Ed.), 21st century communication: A reference handbook. (pp. 82-90). Thousand Oaks, CA: SAGE Publications, Inc. Grunig, Larissa A.; Toth, Elizabeth

Duffield, C. (2010). The illegal but lucrative trade in educational materials, for instance, cripples the work of teachers. Bbc.co.uk. Retrieved 2018-06-21.

Friedrichs, D. (2009). Trusted Criminals. Wadsworth, Belmont, C.A

Heidersohn, F. (2002). Gender and crime in the oxford handbook of criminology. United Kingdom: Oxford.

Jideofor A. (2012). Poverty alleviation in Nigeria: Which way Nigeria? Holler Africa - Make Yourself Heard! Africa: Holler.

Baylis, J., Owens, P., \& Smith, S. (2001). The globalization of world politics. United Kingdom: Oxford University Press.

Linda, C. (2000). Feminist values in public relations. Journal of Public Relations Research, 12(1), 49-68

Maggie, H. (2003). Modernist women and visual cultures. Rutgers University Press.

Nigerian Bureau of Statistics. (2010). Labour force statistics. Nigerian Bureau of Statistics. 2010. Archived from the retrieved 10 June 2019.

Obodo, E. (2014). The Nigerian Banking Award 2014. Business Day Online. Business Day.

Stubbs, J. (2004). Restorative justice, domestic violence and family violence. Australian Domestic and Family Violence, Clearinghouse Issue, Paper, 9.

Weatherburn, D. (2002). Law and order blues. Australian Journal of Criminology, 35(2).

Yusuf, A. (2014). The Informal Sector and Employment Generation in Nigeria.

\section{Copyrights}

Copyright for this article is retained by the author(s), with first publication rights granted to the journal.

This is an open-access article distributed under the terms and conditions of the Creative Commons Attribution license (http://creativecommons.org/licenses/by/4.0/) 